\title{
Multi-method Study on Aquatic Humic Substances from the "Rio Negro" - Amazonas State/Brazil. Emphasis on Molecular-Size Classification of their Metal Contents
}

\author{
J.C. Rocha ${ }^{\mathrm{a}}$, É. Sargentini Jr ${ }^{\mathrm{b}}$, I.A.S. Toscano ${ }^{\mathrm{a}}$, A.H. Rosa $^{\mathrm{a}}$, and P. Burba ${ }^{\mathrm{c}}$ \\ ${ }^{\mathrm{a}}$ Institute of Chemistry, UNESP, C.P. 355, 14800-900 Araraquara - SP, Brazil \\ ${ }^{\mathrm{b}}$ INPA, C.P. 478, 69083-000 Manaus - AM, Brazil \\ ${ }^{\mathrm{c}}$ Institute of Spectrochemistry and Applied Spectroscopy (ISAS), PO Box 101352, \\ D-44013 Dortmund, Germany
}

\begin{abstract}
As substâncias húmicas aquáticas investigadas foram convencionalmente extraídas de amostra de água coletada no Rio Negro - AM, Brasil utilizando-se resina XAD 8. Investigações usando ressonância nuclear magnética de próton e carbono treze indicaram a presença de alta aromaticidade com pouca substituição, pequena quantidade carbono carboxílico e razão 1:1 de grupos alifáticos /

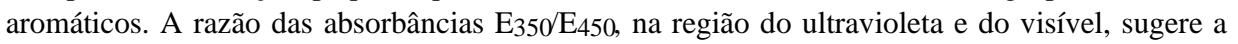
presença de estruturas alifáticas em proporções relativamente grandes. A distribuição do peso molecular das substâncias húmicas aquáticas foi caracterizada utilizando-se um sistema de ultra filtração de 5 estágios. $\mathrm{O}$ fracionamento indicou que metais traço, originalmente complexados com as substâncias húmicas, apresentam diferentes distribuições.
\end{abstract}

The aquatic humic substances investigated in this study were conventionally isolated from Rio Negro waters - Amazonas State/Brazil by means of the collector XAD 8. Molecular spectroscopy investigations of these humic substances using ${ }^{1} \mathrm{H}-\mathrm{NMR}$ and ${ }^{13} \mathrm{C}-\mathrm{NMR}$ indicated the presence of high aromaticity with few substituents, small amounts of carboxylic carbon, and an aliphatic/aromatic ratio of 1:1. The relatively high UV-VIS absorbance $\mathrm{E}_{350} / \mathrm{E}_{450}$ ratio suggested the presence of relatively large proportions of aliphatic structures. Moreover, using a five-stage tangential-flow ultrafiltration (UF) device, the molecular-size distribution of the isolated humic substances was characterized. The fractionation patterns showed that metal traces remaining in humic substances after their XAD 8 isolation have different size distributions. For instance, $\mathrm{Mn}, \mathrm{Cu}, \mathrm{Cd}$ and $\mathrm{Ni}$ quantified by ICP-AES were preferably found in the high molecular-weight fractions (10-100 kDa).

Keywords: aquatic humic substances, Rio Negro, nuclear magnetic resonance, trace metals, molecular-size distribution, multistage ultrafiltration

\section{Introduction}

The main pool of dissolved organic carbon in tropical aquatic environments, notably in the best known dark-coloured river of the Amazon basin, Rio Negro, is concentrated in humic substances (HS). Rio Negro is one of the major tributaries of the Amazon River. According to Ertel and co-workers ${ }^{1}$, the major humic acid flux to the Amazon River system is from the Rio Negro, which corresponds to 2.5 times the input of Rio Solimões. Owing to the loss of cations during cycles of extensive weathering and leaching, the soils in the Amazon Basin are generally infertile ${ }^{2}$. Thus, the metal ions are probably leached to the aquatic systems and complexed by aquatic humic substances (aquatic HS).

Aquatic HS are large organic molecules formed by micro-biotic degradation of biopolymers and polymerisation of smaller organic molecules in the environment ${ }^{3}$. HS in natural waters are polyelectrolytes with a generally irregular structure, and a wide range of molecular weights. The study of metal-humic interactions is often aimed at predicting the effect of HS on the bioavailability of metal ions in the environment ${ }^{4,5}$. Therefore, the characterization of functional groups by spectroscopic methods as well as a 
better knowledge of metal-HS interactions in different molecular-size fractions is important.

Lately, various researchers ${ }^{6-9}$ have studied the properties of aquatic HS. The presence of carboxylic, phenolic and carbonyl groups gives aquatic HS a high capability for the complexation of metal ions. This chemical behavior significantly influences the transport, distribution and accumulation of metals in aquatic environments ${ }^{10,11}$.

In the present work the different functional groups of aquatic HS isolated from Rio Negro ${ }^{12}$ were investigated by means of ${ }^{1} \mathrm{H}-\mathrm{NMR},{ }^{13} \mathrm{C}-\mathrm{NMR}$ and UV/VIS spectroscopy. Moreover, a sequential-stage ultrafiltration procedure ${ }^{13}$ served for the size-classification of the isolated HS. The distribution of metal contained in the obtained HS fractions was assessed by ICP-AES. Information about the humification degree of the different HS fractions could be obtained by UV-VIS spectrometry.

\section{Experimental}

\section{Chemicals and reagents}

All reagents used were of high-purity grade unless otherwise stated. Diluted acid and alkaline solutions necessary for the aquatic HS isolation, were prepared by convenient dilution of $30 \%$ hydrochloric acid (suprapur, Merck AG) or sodium hydroxide-monohydrate (suprapur Merck AG) dissolved in high-purity water (Milli-Q system, Millipore). The XAD 8 adsorbent (Serva Feinbiochemica), required for the isolation of aquatic HS, was previously purified by successive soaking with $0.5 \mathrm{~mol} / \mathrm{L} \mathrm{HCl}, 0.5$ $\mathrm{mol} / \mathrm{L} \mathrm{NaOH}$ and methanol (24 h each).

\section{Isolation of aquatic humic substances by XAD 8 resin}

The HS under study were isolated from a sample collected from Rio Negro - Amazon State/Brazil - near the confluence of the Tarumã Mirim River (Fig. 1). For this purpose, $50 \mathrm{~L}$ of surface water were field filtered through $0.45 \mu \mathrm{m}$ cellulose-based membranes and acidified with concentrated $\mathrm{HCl}$ to $\mathrm{pH}$ 2.0. Afterwards, the $\mathrm{HS}$ from the acidified sample were conventionally isolated on the XAD $8^{14}$ collector following the recommendations of Malcom ${ }^{15}$. After elution with $0.1 \mathrm{~mol} / \mathrm{L} \mathrm{NaOH}$, the obtained concentrate $(3.0 \mathrm{mg} / \mathrm{mL}$ DOC equivalent to $6.0 \mathrm{mg} / \mathrm{mL} \mathrm{HS})$ was neutralized to $\mathrm{pH} 7.0$ with $0.1 \mathrm{HCl}$ solution, stored in high density polyethylene containers and maintained at $4{ }^{\circ} \mathrm{C}$. The determination of dissolved organic carbon (DOC) contained in the water sample and in the HS concentrate was carried out by catalytic combustion in an oxygen stream and subsequent IR detection by Analyser Schimadzu TOC $2000^{16}$.

\section{Complexation}

The complexing capacity of the aquatic HS under study was determined by a copper(II) selective electrode (WTW
$\mathrm{Cu}$ 500). For this purpose, $2.0 \mathrm{mg} \mathrm{HS}$ dissolved in $100 \mathrm{~mL}$ of $0.1 \mathrm{~mol} / \mathrm{L} \mathrm{NaNO}_{3}$ solution ( $\mathrm{pH} 5.0$ ) was successively loaded with $\mathrm{Cu}$ (II) ions and the increase of the electrode potential referring to the added $\mathrm{Cu}$ (II) was recorded. The assessment of the $\mathrm{Cu}$ (II) complexation capacity (CC) was carried out according to Buffle ${ }^{17}$ and Soares et. al. ${ }^{18}$ yielding a $\mathrm{CC}$ of $2.8 \mathrm{mmol} \mathrm{Cu}(\mathrm{II})$ per $\mathrm{g}$ DOC of HS.

\section{Fractionation of the aquatic humic substances by multistage ultrafiltration (UF)}

The aquatic HS under study were on-line fractionated by means of a special tangential-flow multistage ultrafiltration unit developed by Burba and co-workers ${ }^{13,19}$. It consists of a cascade of up to 5 UF stages made of high-purity acrylic polymer attached by two bolts and nuts. The UF stages are equipped with appropriate $25 \mathrm{~mm}$ diameter UF membranes (Pall-Filtron Omega), leading to the separation of the following molecular-size fractions: $\mathrm{F}_{1},>100 ; \mathrm{F}_{2}$, 50-100; $\mathrm{F}_{3}, 10-50 ; \mathrm{F}_{4}, 5-10 ; \mathrm{F}_{5}, 1-5$ and $\mathrm{F}_{6}<1$ kDalton. The tangential-low UF processing was performed by a fivechannel peristaltic pump. Accordingly, the aquatic HS solution (10 mL $1.0 \mathrm{mg} / \mathrm{L} \mathrm{HS}, \mathrm{pH} 6.0)$ was pumped (initial pressure, 2.5 bar) through the cascade of membranes leading to a flow rate of 1.5 to $2 \mathrm{~mL} / \mathrm{h}$ (tangential flow, 2-3 $\mathrm{mL} / \mathrm{min})$.

\section{UV/VIS and ICP-AES}

UV/VIS spectra of aquatic-HS and their ultrafiltrated fractions were registered in the $225-600 \mathrm{~nm}$ range with a two beam Varian Cary 1/3 spectrometer. The metals bound to the fractions ( $\mathrm{F}_{1}$ to $\mathrm{F}_{6}$ ) were determined by ICP-AES, using for this purpose, a Thermo Jarrel Ash - CID-DUO Spectrometer, according to the experimental conditions given in Table 1.

\section{NMR spectrometry}

The ${ }^{1} \mathrm{H}-\mathrm{NMR}$ spectrum of the $\mathrm{D}_{2} \mathrm{O}$ dissolved aquatic HS sample, referred to acetonitrile, was measured at 400 MHz using a JEOL GX 400 NMR spectrometer according to the following experimental conditions: acquisition time: $1.59 \mathrm{~s}$; total time: $11 \mathrm{~min}$; sweep width: $5160 \mathrm{~Hz}$; number

Table 1. Operating parameters for the ICP-AES determinations.

\begin{tabular}{lc}
\hline Operating parameters & \\
\hline Incident power & $1.5 \mathrm{~kW}$ \\
Plasma Air flow-rate & $15 \mathrm{~L} / \mathrm{min}$ \\
Nebulizer Air flow-rate & $1.2 \mathrm{~L} / \mathrm{min}$ \\
Auxiliary Air flow-rate & $0.5 \mathrm{~L} / \mathrm{min}$ \\
Sample flow-rate & $2.4 \mathrm{~mL} / \mathrm{min}$ \\
Analytical lines & $\mathrm{Cd} 396.8\{066\}, \mathrm{Cu} 327.4$ \\
& $\{079\}, \mathrm{Ni} 221.6\{117\}, \mathrm{Co} 228.6$ \\
& $\{114\}, \mathrm{Mn} 257.6\{100\} \mathrm{nm}$ \\
\hline
\end{tabular}


of scans: 256; resolution: $8 \mathrm{k}$. The ${ }^{13} \mathrm{C}-\mathrm{NMR}$ spectrum of $250 \mathrm{mg} \mathrm{HS}$ dissolved in $3.0 \mathrm{~mL} \mathrm{D}_{2} \mathrm{O}(\mathrm{pH} 8.5)$ referred to acetonitrile, was measured at $100 \mathrm{MHz}$ with a JEOL GX 400 NMR spectrometer according to the following experimental conditions: acquisition time: $0.34 \mathrm{~s}$; total time: 62 h; sweep width: $48078 \mathrm{~Hz}$; resolution: $16 \mathrm{k}$.

\section{Results and Discussion}

The origin and other information related to the studied aquatic humic substances are summarized in Tables 2, 3 and Fig. 1.

\section{NMR studies}

${ }^{1} \mathrm{H}-\mathrm{NMR}$ was used to estimate the relative contents of aromatic and aliphatic protons in the aquatic HS. Figure 2 shows the ${ }^{1} \mathrm{H}-\mathrm{NMR}$ spectrum with signals attributed to aliphatic protons $(0-4.5 \mathrm{ppm})$, and aromatic and heteroaromatic hydrocarbons (6 - $8 \mathrm{ppm}$ ) (Table 4). The peaks from 1.6 to $3.0 \mathrm{ppm}$ can be explained by the presence of the methyl and methylene groups which are $\alpha$ or attached to electronegative groups, e.g., carboxyl group or an aromatic ring. Protons on carbons bonded to $\mathrm{O}$ or $\mathrm{N}$ heteroatoms were characterized by peaks between $3.3-4.5 \mathrm{ppm}$. The sharp peak which appears at $4.9 \mathrm{ppm}$ can be attributed to the traces of $\mathrm{H}_{2} \mathrm{O}$ in the $\mathrm{D}_{2} \mathrm{O}$ and the peaks at 5 - 6 ppm may

Table 2. Complementary information related to the humic substances from Rio Negro (February, 1997).

\begin{tabular}{lc}
\hline Origin & Rio Negro (at Tarumã Mirim) \\
\hline $\mathrm{pH}$ & 6.5 \\
Conductivity & $58 \mu \mathrm{S} \mathrm{cm}^{-1}$ \\
Temperature & $27^{\circ} \mathrm{C}$ \\
DOC & $12 \mathrm{mgC} / \mathrm{L}$ \\
Complexation capacity & $2.8 \mathrm{mmol} \mathrm{Cu}(\mathrm{II}) / \mathrm{g}$ DOC \\
\hline
\end{tabular}

Table 3. Concentration of the trace metals in water and in the humic substances isolated from Rio Negro $(n=4)$.

\begin{tabular}{lcc}
\hline Metals & \multicolumn{2}{c}{ Concentration } \\
\cline { 2 - 3 } & Water $^{\mathrm{a}}[\mu \mathrm{g} / \mathrm{L}]$ & Isolated HS ${ }^{\mathrm{b}}[\mu \mathrm{g} / \mathrm{g}]$ \\
\hline $\mathrm{Cu}$ & 7.3 & $5.3 \pm 0.3$ \\
$\mathrm{Co}$ & $\leq^{\mathrm{c})}$ & $8.4 \pm 0.6$ \\
$\mathrm{Ni}$ & 28 & $8.0 \pm 0.5$ \\
$\mathrm{Cd}$ & $\leq^{\mathrm{c})}$ & $4.5 \pm 0.2$ \\
$\mathrm{Mn}$ & 49 & $44 \pm 2.2$ \\
\hline
\end{tabular}

${ }^{\mathrm{a}}$ Total metals in the $0.45 \mu \mathrm{m}$ membrane filtered original sample.

${ }^{\mathrm{b}}$ After isolation by the XAD 8 resin procedure.

${ }^{\mathrm{c}}$ Below the detection limit of ICP-AES.

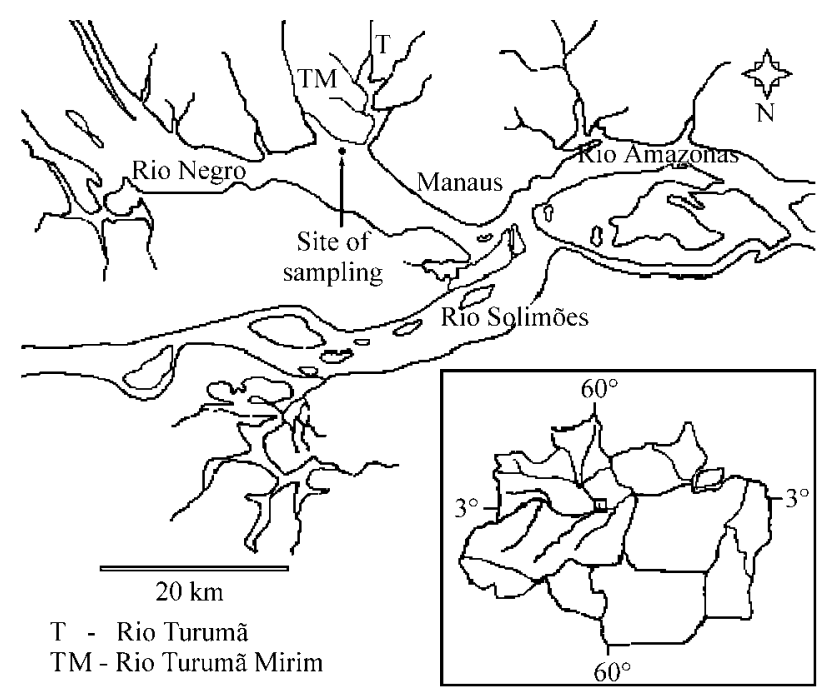

Figure 1. Rio Negro and the sampling location site.

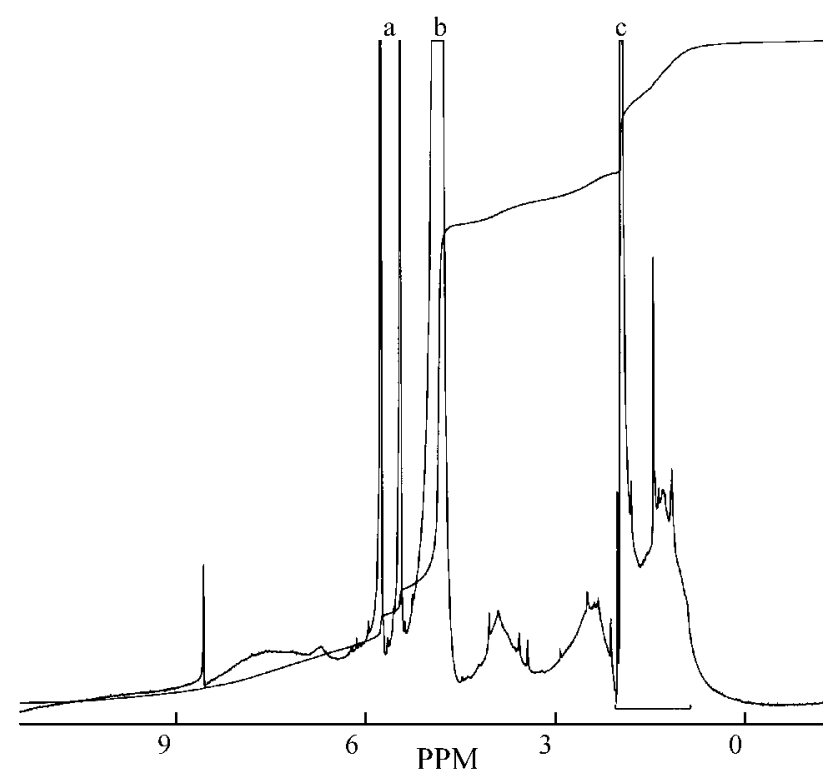

Figure 2. ${ }^{1} \mathrm{H}-\mathrm{NMR}$ spectrum of the studied humic substances isolated from the Rio Negro. Chemical shifts (ppm) referred to acetonitrile.

a) XAD 8 acrylesther peak.

b) Water.

c) Acetonitrile.

be due to the acrylester groups extracted from the XAD 8 resin.

${ }^{13} \mathrm{C}$-NMR is a well suited technique for the examination of complex organic structures such as those present in soil and waters ${ }^{20}$. Although NMR does not allow assessment of the complete structure of the compounds, it does provide a measure of the average distribution of the various types of carbons. The direct measurements of the carboxyl, aromatic and aliphatic carbon contents can often be made by peak integration of their specific regions. 
Table 4. Peak assignments for the ${ }^{1} \mathrm{H}-\mathrm{NMR}$ spectrum of the studied humic substances from Rio Negro and their integrated areas (\%).

\begin{tabular}{|c|c|c|}
\hline$(\mathrm{ppm})$ & Assignments & Integration $\%$ \\
\hline $0-1.6$ & $\mathrm{C}-\mathrm{CH}_{\mathrm{n}}(\mathrm{n}=2 ; 3)$ & 28 \\
\hline $1.6-3.0$ & $\begin{array}{l}(\mathrm{O})-\mathrm{CO}-\mathrm{CH}_{\mathrm{n}} \\
\text { Aliphatic protons } \\
\text { attached } \mathrm{C} \text { atom } \alpha \\
\text { to a benzene ring }\end{array}$ & 25 \\
\hline $3.3-4.5$ & $\begin{array}{c}\mathrm{O}-\mathrm{CH}_{\mathrm{n}} \\
\mathrm{N}-, \mathrm{CH}_{\mathrm{n}} \\
(\mathrm{n}=1 ; 2)\end{array}$ & 13 \\
\hline $5.5-9.0$ & $\begin{array}{c}\text { Olefinic and } \\
\text { Aromatic }\end{array}$ & 34 \\
\hline
\end{tabular}

Figure 3 shows the ${ }^{13} \mathrm{C}$-NMR spectrum of aquatic-HS. Peaks can be attributed to the presence of the same groups present in the ${ }^{1} \mathrm{H}-\mathrm{NMR}$ spectrum, i.e., aliphatic $(0-60$ ppm), aromatic carbons, carbonyl (100 - 160 ppm) and carboxyl groups $(160-180 \mathrm{ppm})$. Similar trends were observed in the ${ }^{13} \mathrm{C}-\mathrm{NMR}$ spectrum of HS samples from Como $\mathrm{Creek}^{21}$, with comparable aliphatic and aromatic contributions.

The ${ }^{1} \mathrm{H}$-NMR and ${ }^{13} \mathrm{C}$-NMR spectra indicate that the quantity of aliphatic carbons seems to be greater or, at least, of the same magnitude of the aromatic carbons. The ${ }^{1} \mathrm{H}-$ NMR spectrum integration shows that aquatic HS exhibit $34 \%$ of aromatic and $28 \%$ of aliphatic hydrogens. The ${ }^{13} \mathrm{C}$-NMR spectrum shows $35 \%$ aromatic and $33 \%$ aliphatic carbons (Table 5). It is worth noting that these results show the presence of high aromaticity with few substi-

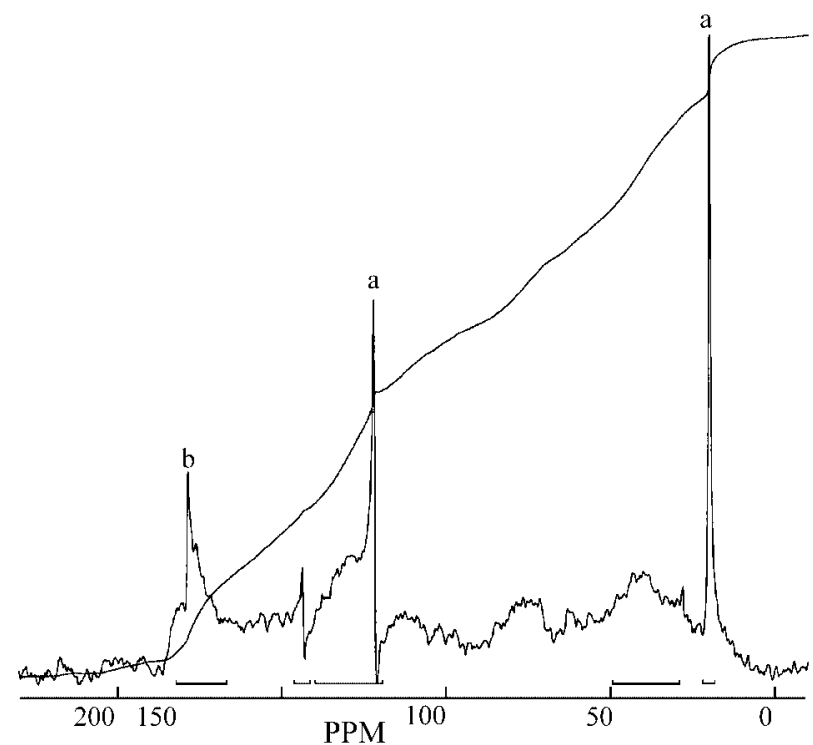

Figure 3. ${ }^{13} \mathrm{C}-\mathrm{NMR}$ spectrum of the studied Rio Negro humic substances. Chemical shifts (ppm) referred to acetonitrile.

a) Acetonitrile.

b) Blanks of acrylester dissolved from XAD 8.
Table 5. Peak assignments for the ${ }^{13} \mathrm{C}-\mathrm{NMR}$ spectra of the studied humic substances from Rio Negro and their integrated areas (\%).

\begin{tabular}{lcc}
\hline$(\mathrm{ppm})$ & Assignments & Integration \% \\
\hline $65-0$ & Paraffin & 33 \\
$100-65$ & Hydroxyl, Ether & 17 \\
$165-100$ & Olefinic, Aromatic & 35 \\
$190-165$ & Carboxyl & 12 \\
$230-190$ & Ketone & 3 \\
\hline
\end{tabular}

tuents, small amount of carboxylic carbon (12\%) and 1:1 (aliphatic : aromatic) ratio.

\section{Ultrafiltration studies}

Figure 4 shows the molecular-size distribution of studied Rio Negro HS in the ultrafiltration fractions from $F_{1}$ to $\mathrm{F}_{6}$. The loss in the recovery balance, about $7 \%$, might be attributed to the adsorption onto the inner surface of the UF device $^{13}$. Most of the mass of this HS is concentrated in the middle fraction $\mathrm{F} 3(10-50 \mathrm{kDa}, 31.5 \%)$ and in the $\mathrm{F}_{2}$ fraction $(50-100 \mathrm{kDa}, 23.3 \%)$ showing a relatively high molecular-weight.

Gaffney et $a .^{22}$ reports that DOC distribution for the Volo Bog water is concentrated in the size ranges of 30-3 $\mathrm{kDa}$ and $<3 \mathrm{kDa}$. However, a DOC profile for a water sample collected at Saganashkee Slough, with higher nutrient content than the bog, showed the humic material concentrated at the 0.45 to $0.1 \mu \mathrm{m}$ and $<3 \mathrm{kDa}$ fractions. It is worth noting that the distribution patterns of different HS containing samples can be compared only if the separation is carried out under the same conditions.

The analysis of these fractions demonstrates that acidinert metal traces still retained in this HS after its XAD 8 isolation from the acidified water sample $(\mathrm{pH} 2.0)$ have different distributions in the obtained HS, as shown in Figure 5. The content of Co traces in the different fractions seems to be similar except for the $\mathrm{F}_{4}$ fraction, that contains about $30 \%$ of the total HS bound Co. Such distribution

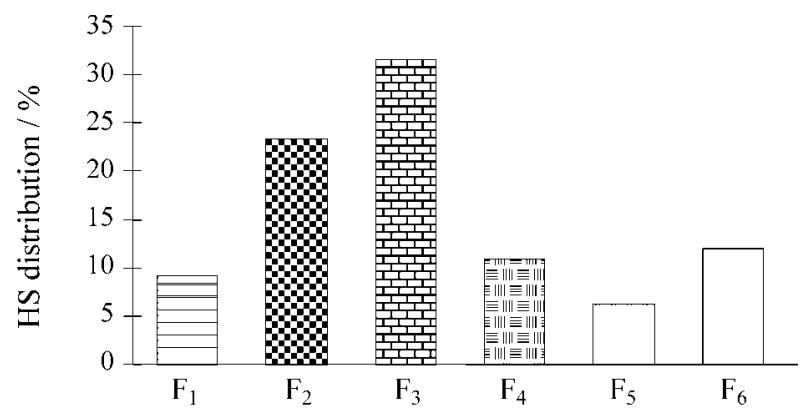

Figure 4. Molecular distribution pattern of the studied Rio Negro humic substances obtained after a five-stage on line ultrafiltration (conditions: 1 $\mathrm{mg} / \mathrm{mL}$ HS, pH 6.0, F1 > 100; F2, 50-100; F3, 10-50; F4, 5-10; F5, 1-5; $\mathrm{F}_{6},<1$ kDalton). 


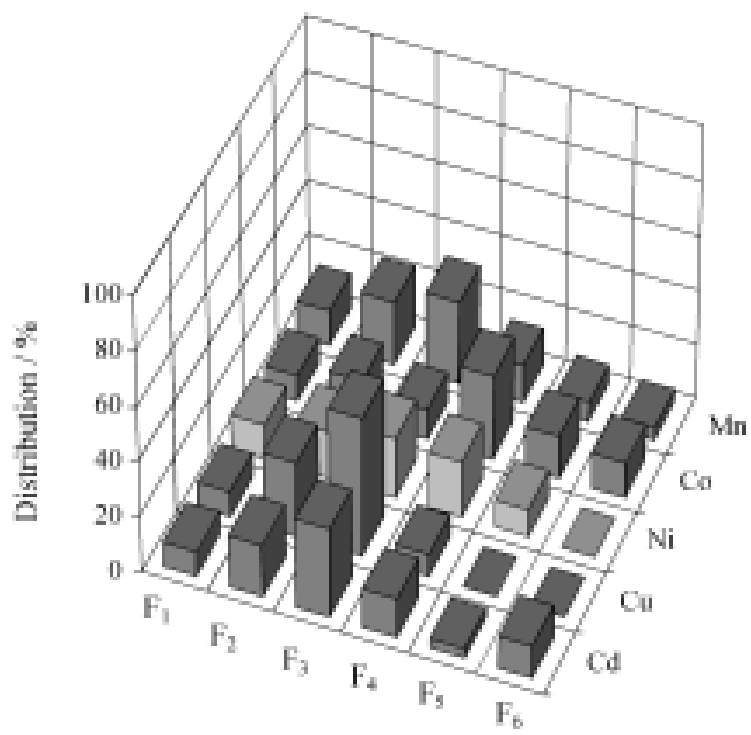

Figure 5. Distribution traces of $\mathrm{Mn}, \mathrm{Co}, \mathrm{Ni}, \mathrm{Cu}, \mathrm{Cd}$ contained in XAD 8 isolated Rio Negro humic substances (conditions: $1.0 \mathrm{mg} / \mathrm{mL} \mathrm{HS}$; $\mathrm{pH} 6.0$, fractionation as in Fig. 4).

indicates that there are no specific sites in the different fractions of HS related to the acid-inert Co. However, acid-inert $\mathrm{Mn}, \mathrm{Cu}$ and $\mathrm{Cd}$ were in general preferably bound by molecules of relatively high molecular-weight $\left(\mathrm{F}_{2}\right.$ and $\mathrm{F}_{3} ; 10-100 \mathrm{kDa}$ ). The Ni traces of this isolated HS presented similar distribution patterns in the high-molecular weight fractions, $\mathrm{F}_{1}$ to $\mathrm{F}_{4}$. Using a natural bog water sample and a similar fractionation procedure, Burba and co-workers ${ }^{13}$ showed that original Mn is preferably complexed by low molecular-weight $(<1 \mathrm{kDa}) \mathrm{HS}$ fractions. Gaffney et al. ${ }^{22}$ demonstrated that the organic fraction of $0.1 \mu \mathrm{m}$ and 100 $\mathrm{kDa}$ contained an appreciable manganese content. Rottmann and Heumann ${ }^{23}$ applied a HPLC system on line coupled with ICP-MS for the heavy metals study of different fractions of dissolved organic matter. For $\mathrm{Cu}$, the major amount was complexed with the high molecular-weight fractions. Moreover, the same metal ions also showed different fingerprints for samples of different origins.

\section{UV spectrometric studies}

A number of investigators have reported a strong correlation between the structure of HS and their ability to bind organic and inorganic pollutants. In recent spectroscopic studies a significant correlation was observed between molar absorptivity $(\varepsilon)$, total aromaticity, and the molecular weights of HS. The percent of aromatic carbon, determined by NMR, was correlated with UV-absorbance measurements $^{24}$. It was suggested that the UV-absorbance can be used to provide a rapid and quantitative estimate of the aromatic nature of the dissolved HS. In essence, an average molar absorptivity $(\varepsilon)$, based on the whole sample, was used to determine the concentration of material passing through the detector ${ }^{25}$. It could be demonstrated that this spectroscopic property of the HS vary with their molecular weight. The high molecular weight fractions of HS have a larger average $\varepsilon$, while the low molecular HS weight fractions, showed a smaller average molar absorptivity.

According to Chen and co-workers ${ }^{26}$, the magnitude of the absorbance ratio $\mathrm{E}_{4} / \mathrm{E}_{6}$ (absorbances at 400 and $600 \mathrm{~nm}$ ) depends on the humification degree (decomposition of organic matter) and the molecular weight of HS molecules. This quotient is widely used in soil science as an indicator for humification. However, Peuravuori ${ }^{27}$ has found no relationship between the aromaticity and the absorbance ratio $\mathrm{E}_{4} / \mathrm{E}_{6}$, in limnologycal studies. Instead, the correlation between the $\mathrm{E}_{2} / \mathrm{E}_{3}$ ratio (absorbances at 250 and $365 \mathrm{~nm}$ ) and the molar absorptivity $(\varepsilon)$ at $280 \mathrm{~nm}$ was quite moderate $\left(\mathrm{r}^{2}\right.$ $=0.81$ ). The authors suggested that the relationship between the aromaticity and the $\mathrm{E}_{2} / \mathrm{E}_{3}$ ratio for humic materials could be obtained according to

aromaticity $=52.509-6.780 \mathrm{E}_{2} / \mathrm{E}_{3}$

This implies that when the quotient $\mathrm{E}_{2} / \mathrm{E}_{3}$ increases, the aromaticity and the molecular size of the aquatic humic solutes decreases. Chen et l. $^{26}$, also observed a good correlation between aromaticity of HS and $\varepsilon$ at $280 \mathrm{~nm}$ :

$$
\text { aromaticity }=0.05 \varepsilon+6.74 ; \mathrm{r}^{2}=0.90
$$

as well as a good correlation between molecular weight and $\varepsilon$ :

$$
\mathrm{M}_{\mathrm{w}}=3.99 \varepsilon+490 ; \mathrm{r}^{2}=0.97
$$

Although the $\mathrm{E}_{2} / \mathrm{E}_{3}$ ratios appear to be more appropiate to limnologycal studies, the $\mathrm{E}_{350} / \mathrm{E}_{450}$ ratios (absorbances at 350 and $450 \mathrm{~nm}$ ) were chosen due to the high absorbance values presented by the $F_{1}, F_{2}$ and $F_{3}$ fractions at $250 \mathrm{~nm}$. Taking into account such discussion, Table 6 shows the $\mathrm{E}_{350} / \mathrm{E}_{450}$ ratios observed to the the Rio Negro HS fractions obtained by multistage UF. Accordingly, a low $\mathrm{E}_{350} / \mathrm{E}_{450}$ ratio value of the (e.g. $\left.\mathrm{F}_{1}-\mathrm{F}_{2}\right)$ might be indicative of a relatively high degree condensation of aromatic humic

Table 6. On-line ultrafiltration of the isolated Rio Negro humic substances: molecular-size distribution and absorbance ratio of $\mathrm{E}_{350 \mathrm{~nm} / \mathrm{E}} / 50 \mathrm{~nm}$

\begin{tabular}{lcc}
\hline Fraction & Amount $(\%)$ & $\mathrm{E}_{350 \mathrm{~nm}} / \mathrm{E}_{450 \mathrm{~nm}}$ \\
\hline Original sample & 100 & 6.33 \\
$\mathrm{~F}_{1}(>100 \mathrm{kDa})$ & 9.3 & 4.04 \\
$\mathrm{~F}_{2}(50-100 \mathrm{kDa})$ & 23.3 & 5.44 \\
$\mathrm{~F}_{3}(10-50 \mathrm{kDa})$ & 31.5 & 6.57 \\
$\mathrm{~F}_{4}(5-10 \mathrm{kDa})$ & 10.9 & 7.35 \\
$\mathrm{~F}_{5}(1-5 \mathrm{kDa})$ & 6.3 & 7.43 \\
$\mathrm{~F}_{6}(<1 \mathrm{kDa})$ & 12.1 & 14.7 \\
\hline
\end{tabular}


substructures. Moreover, the increase of the $\mathrm{E}_{350} / \mathrm{E}_{450}$ ratio may be related to a continuous decrease of the molecular weight from fractions $\mathrm{F} 3$ to $\mathrm{F}_{6}$. However this behavior, can also be associated with the presence of relatively larger proportions of aliphatic structures.

\section{Conclusions}

From this multimethodological study of HS isolated from Rio Negro water the following conclusions can be drawn. The molecular spectroscopy investigations $\left({ }^{1} \mathrm{H}-\right.$ NMR, ${ }^{13} \mathrm{C}-\mathrm{NMR}$ and UV/Vis) indicated the presence of high aromaticity with little substitution and small amount of carboxylic carbon in the studied HS. The absorbance ratio $E_{350} / E_{450}$ suggests the presence of relatively large proportions of aliphatic structures. Molecular size fractionation of the HS after its acidic XAD8 isolation from Rio Negro water revealed that the trace metals have different size distributions. Generally, the acid-inert traces of $\mathrm{Mn}$, $\mathrm{Cu}, \mathrm{Cd}$ and $\mathrm{Ni}$ were preferably bound to the molecularweight fractions of $>10 \mathrm{kDa}$.

Summarizing, a multimethod approach consisting of powerful fractionation, molecular and atomic spectrometry methods is required to characterize aquatic HS and their complex metal interactions in tropical aquatic environments, (e.g. Rio Negro).

\section{Acknowledgements}

This work has been financially supported by FAPESP (Proc. 95/05231-0 and 97/10673-8 / CNPq - Brazil) and DAAD (Germany). The authors are indebted to Miss Brit Aster and Helmut Herzog from ISAS (Germany) for performing multistage ultrafiltration and NMR measurements, respectively.

\section{References}

1.Ertel, J.R.; Hedges, J.I.; Devol, A.H.; Richey, J.E.; Ribeiro, M.N.G. Limnol. Oceanogr. 1986, 31, 739.

2.Herrera, R.; Jordan, C.F.; Klingle, H.; Medina, E. Interciencia 1978, 3, 223.

3. MacCarthy P.; Suffet, I.M., Eds. Aquatic Humic Substances. Influence on Fate and Treatment of Pollutants; American Chemical Society; Washington, DC, Symposium Series, 1989, v. 219, p. xvii.

4. Campbell, P.G.C.; Tessier, A. In Metals speciation, separation and recovery; Patterson, J.W.; Passino, R., eds.; Lewis Publishers; Michigan, 1987, v. 1, p. 201.

5.Lund, W. In Metal Speciation in the Environment, Broekaert, J.A.C.; Güçer, S.; Adams, F., eds.; NATO ASI Series; Springer-Verlag; Berlim, 1990, v. 23, p. 43.

6. Senesi, N. In Organic Substances in Soil and Water: Natural Constituents and their Influences on Contaminant Behaviour, Beck, A.J.; Jones, K.C.; Hayes,
M.H.B.; Mingelgrin, U., eds.; Royal Society of Chemistry; Cambridge, 1993, p. 73.

7. Leenheer, J.A. In Environmental Chemistry of Lakes and Reservoirs; Baker, L.A., Ed.; American Chemical Society; Washington, DC, 1994, Advanced in Chemistry Series v. 237, p. 195.

8. Burba, P.; Rocha, J.C.; Klockow, D. Fresenius J. Anal. Chem. 1994, 34, 800.

9. Rocha, J.C.; Toscano, I.A.S.; Burba, P. Talanta 1997, 44, 69.

10. Hirade. M. Analytical Science 1992, 8, 455.

11. Weber, J.M. In Humic Substances and their Role in the Environment; Frimmel, F.H.; Christman, R.F, .eds.; John Wiley \& Sons; Chichester, 1998, p. 165.

12. Rocha, J.C.; de Sene, J.J.; Burba, P. Klockow. D. J. Braz. Chem. Soc. 1998, 9, 79.

13. Burba, P.; Shkinev, V.; Spivakov, B.Y. Fresenius J. Anal. Chem. 1995, 351, 74.

14. Aiken, G.R. In Humic Substances in Soil, Sediment and Water. Geochemistry, Isolation and Characterization; Aiken, G.R.; MacKnight, D.M.; Wershaw, R.L.; MacCarthy, P., eds.; John Wiley \& Sons; New York, 1985, p. 363.

15. Malcom, R.L. In Humic Substances in the aquatic and terrestrial environment. Allard, B., Boren, H., Grimvall, A., eds.; Springer-Verlag; Berlim, 1989, p. 9.

16. Wangersky, P.J. Marine Chemistry 1993, 41, 61.

17. Buffle, J. In Complexation Reactions in Aquatic Systems: an analytical Approach. Ellis Horwood, Chichester, UK, 190, p. 427.

18. Soares, H.M.V.M.; Vasconcelos, M.T.S.D. Anal. Chim. Acta 1994, 293, 261.

19. Aster, B.; Burba, P.; Broekaert, J.A.C. Fresenius J. Anal. Chem. 1996, 354, 722.

20. Swift, R.S. In Methods of soil analysis. Part 3. Chemical methods. Soil Science Society of America and American Society of Agronomy, Madison, 1996, p. 1011.

21. Mills, M.S.; Thurman, E.M.; Ertel, J.;Thorn, K.A. In Humic and Fulvic Acids. Isolation, Structure, and Environmental Role; Gaffney, J.S.; Marley, N.A.; Clark, S.B., Eds.; American Chemical Society; Washington, DC, Symposium Series, 1996, v. 651, p. 151.

22. Gaffney, J.S.; Marley, N.A.; Orlandini, K.A In Humic and Fulvic Acids. Isolation, Structure, and Environmental Role, Gaffney, J.S.; Marley, N.A.; Clark, S.B. Eds.; American Chemical Society; Washington, DC, Symposium Series, 1996, v. 651, p. 26.

23. Rottmann, L.; Heumann, K.G. Anal. Chem. 1994, 66, 3709. 
24. Traina, S.J.; Novak, J.; Sneck, N.E. J. Environ. Qual. 1990, 19, 151.

25. Yu-Ping, C.; Aiken, G.; O’Loughlin, E. Environ. Sci. Technol. 1994, 28, 1853.
26. Chen, Y.; Senesi, N.; Schnitzer, M. Soil Sci. Am. J. 1994, 41, 352.

27. Peuravuori, J.; Pihlaja, K. Anal. Chim. Acta 1997, 337, 133.

Received: June 9, 1998 